\title{
Protective Effect of Terminalia catappa Leaves and Terminalia chebula Fruits on the Enzymatic and Non-enzymatic Anti-oxidant Levels in the Doxorubicin Induced Toxicity Rats
}

\author{
Panneerselvam Punniyakotti ${ }^{1}$, Rengasamy Lakshminarayanan Rengarajan ${ }^{2}$, Shanmugam Velayuthaprabhu ${ }^{3}$, \\ Kalaiyarasan Vijayakumar ${ }^{4}$, Ramasamy Manikandan ${ }^{5}$, Arumugam Vijaya Anand ${ }^{6, *}$
}

\section{Panneerselvam Pun- niyakotti ${ }^{1}$, Rengasamy Lakshminarayanan Ren- garajan ${ }^{2}$, Shanmugam Velayuthaprabhu ${ }^{3}, \mathrm{Ka}-$ laiyarasan Vijayakumar ${ }^{4}$, Ramasamy Manikan- dan $^{5}$, Arumugam Vijaya Anand ${ }^{6, *}$}

'Department of Biochemistry, Manonmaniam Sundaranar University, Abishekapatti, Tirunelveli-627 012, Tamilnadu, INDIA. ${ }^{2}$ Department of Animal Science, Bharathidasan University, Trichy, Tamilnadu, INDIA. ${ }^{3}$ Assistant Professor, Department of Biotechnology, Bharathiar University, Coimbatore641 046, Tamilnadu, INDIA.

${ }^{4}$ Department of Biochemistry, Sri Meenakshi Vidiyal College of Arts and Science, Trichy, Tamilnadu, INDIA.

${ }^{5}$ Department of Biochemistry, MIET Arts and Science College, Trichy, Tamilnadu, INDIA. ${ }^{6}$ Department of Human Genetics and Molecular Biology, Bharathiar University, Coimbatore-641 046, Tamilnadu, INDIA.

\section{Correspondence}

\section{Arumugam Vijaya Anand}

Associate Professor and Head, Department of Human Genetics and Molecular Biology, Bharathiar University, Coimbatore - 641 046, Tamilnadu, INDIA

Phone no :+9198425 25830

E-mail: avamiet@yahoo.com

History

- Submission Date: 26-12-2018;

- Review completed: 07-01-2019;

- Accepted Date: 23-01-2019

DOI : 10.5530/pj.2019.11.51

Article Available online

http://www.phcogj.com/v11/i2

Copyright

(C) 2019 Phcog.Net. This is an open access article distributed under the terms of the Creative Commons Attribution 4.0 International license.

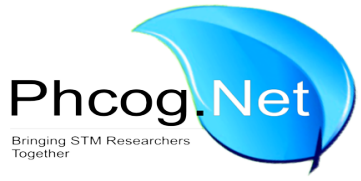

\begin{abstract}
Background: Oxidative stress plays an important role in chronic complications of diabetes, cancer, liver disorder etc. The free radicals such as superoxide anions, hydrogen peroxides are causing the oxidative stress and it involves the cellular damage. Evidences recommended that the natural medicines from plant sources are treated to overcome the oxidative stress complications. Objective: The aim of the present is to find the antioxidant activity of the ethanolic extract of Terminalia catappa leaves and Terminalia chebula fruits in the doxorubicin (DOX) induced toxicity rats. Methods: Oxidative stress is induced with a single dose of doxorubicin and then the animals were treated with a dose of various concentration of ethanolic extract of T. catappa leaves and T. chebula fruits $(200,300 \mathrm{mg} / \mathrm{kg} / \mathrm{b} . \mathrm{w})$ for 21 days. After the treatment, Lipid peroxide (LPO), Reduced glutathione (GSH), vitamin C, vitamin E, Glutathione-s-transferase (GST), Glutathione Peroxidase (GPx), Superoxide dismutase (SOD), catalase levels are determined. Propranolol $25 \mathrm{mg} / \mathrm{kg}$ is used as standard drug. Results: In the present study, after the treatment of doxorubicin the levels of SOD, CAT, GSH, GST, GPX, vitamin C, vitamin $\mathrm{E}$ levels are decreased and LPO level is increased. After the treatment of T. catappa leaves and $T$. chebula fruits the levels were returned to the normal level. Conclusion: The results proved that the ethanolic extract of $T$. catappa leaves and $T$. chebula fruits may protects the cells from oxidative stress induced by the doxorubicin induced toxicity rats.

Key words: Oxidative stress, Enzymatic antioxidant, Non-enzymatic antioxidant, Doxorubicin, Termianlia catappa, Terminalia chebulla.
\end{abstract}

\section{INTRODUCTION}

Numerous chemicals are produced by the plants in different concentrations and the relation between these phytochemical, which helps the plants to fight against various diseases and insects. Due to the highly expensive and side effects, the researchers are trying to find the drugs from the plant sources without any toxic effect. The various phytoconstituents are present in the plants, the compounds have various biological activities. The numerous plants and their parts are used for the medicinal purposes from ancient times. In now-a-days the researchers are trying to find the mechanism of action of the phytoconstituents and developed the new drugs, because these are inexpensive and have no side effects. ${ }^{1}$

\section{Terminalia catappa (T. catappa)}

T. catappa belongs to the Combretaceae family. It highly distributed in the warmer places of Asia. Its other names are Indian almond, Malabar Almond and Tropical Almond. The plant which contains the various phytoconstituents, especially the leaves contains beta- kaempferol, terflavin, gentisic acid and quercetin. The leaves contain the anti-microbial activity, ${ }^{2,3}$ hepatoprotective activity and anti-diabetic activity. ${ }^{4}$

\section{Terminalia chebula (T. chebula)}

T. chebula belongs to the Combretaceae family. The common name is Haritaki, in Tamil Ammai, Amutam, Aritaki, Pethiyam and Varikkai. The tree consists of fruits, bark and root. It contains various phyotconstituents like triterpenoids, coumarin, gallicacid, ethyl gallate etc. ${ }^{5}$ In an ancient time the fruits are used to reduce the swelling and clean the wounds and ulcers. The recent studies prove that the fruits which have the molluscicidal activity, ${ }^{6}$ antiviral activity, ${ }^{7}$ anti-mutangenic activity, anti-cancer activity $^{8}$ and hepatoprotective activity. ${ }^{9}$

Hence, the present study is aimed to evaluate the ant-oxidant activity of ethanolic extract of T. catappa leaves and T. chebulla fruits in the doxorubicin toxicity rats.
Cite this article: Punniyakotti $P$, Rengarajan $R L$, Velayuthaprabhu S, Vijayakumar K, Manikandan $R$, Anand AV. Protective Effect of Terminalia catappa Leaves and Terminalia chebula Fruits on the Enzymatic and Non-enzymatic Anti-oxidant Levels in the Doxorubicin Induced Toxicity Rats. Pharmacog J. 2019;11(2):346-9. 


\section{MATERIALS AND METHODS}

\section{Plant material and extraction}

The fresh T. catappa leaves (MPP 001) and T. chebulla fruits (MPP 002) were collected locally and authenticated by Botanist at Rapinat Herbarium, St. Joseph College, Trichy, Tamil Nadu, India. The extraction of T. catappa leaves and T. chebulla fruits are done by a hot percolation method with Soxhlet apparatus. Ethanol is used as a solvent. About $100 \mathrm{gm}$ of the powder of the plant materials is extracted with $600 \mathrm{ml}$ of ethanol. The extract is concentrated to dryness under controlled temperature of $40-50^{\circ} \mathrm{C}$. Animal's Male albino rats of 6-8 weeks age, weighing 150-180 g is used. The animals are kept in clean, dry plastic cages and fed with standard pellet diet and water. This study is carried out in the animal house of Srimad Andavan Arts and Science College, Trichy and this study is approved by the Institutional Ethical Committee. (CPCSEA Approval No: 790/03/ac/CPCSEA) The animals are divided into nine groups with six rats each.

\begin{tabular}{|c|c|c|}
\hline Group I & : & Control (Standard diet) \\
\hline Group II & : & DOX (1.5 ml/kg b.w) toxic control \\
\hline Group III & : & $\begin{array}{l}\text { Control + Ethanolic leaf extract of T. catappa alone } \\
\qquad(300 \mathrm{mg} / \mathrm{kg} \text { b.w })\end{array}$ \\
\hline Group IV & : & $\begin{array}{l}\text { Control + Ethanolic fruit extract of } T \text {. chebula alone } \\
\qquad(300 \mathrm{mg} / \mathrm{kg} \mathrm{b.w})\end{array}$ \\
\hline Group V & : & DOX + Ethanolic leaf extract of T. catappa $(200 \mathrm{mg} / \mathrm{kg} \mathrm{b.w})$ \\
\hline Group VI & : & DOX + Ethanolic leaf extract of T. catappa $(300 \mathrm{mg} / \mathrm{kg} \mathrm{b.w})$ \\
\hline Group VII & : & DOX + Ethanolic fruit extract of T. chebula $(200 \mathrm{mg} / \mathrm{kg}$ b.w $)$ \\
\hline Group VIII & : & DOX + Ethanolic fruit extract of $T$. chebula $(300 \mathrm{mg} / \mathrm{kg}$ b.w $)$ \\
\hline Group IX & : & DOX + Propranolol (25mg/kg b.w) \\
\hline
\end{tabular}

\section{Biochemical analysis}

The antioxidant status is assessed in the cardiac tissue of the experimental rats. A known weight of the tissue was homogenized in $0.1 \mathrm{M}$ ice cold tris- $\mathrm{HCl}$ buffer $(\mathrm{pH} 7.5)$ to give a $10 \%$ homogenate and used as the source of anti-oxidants. The levels of LPO, ${ }^{10} \mathrm{GSH},{ }^{11} \mathrm{GPx},{ }^{12} \mathrm{SOD},{ }^{13} \mathrm{GST},{ }^{14}$ CAT, ${ }^{15}$ vitamin $\mathrm{C}^{16}$ and vitamin $\mathrm{E}^{17}$ are estimated at the end of the study.

\section{Statistical analysis}

Data were analyzed by one way analysis of variance (ANOVA) followed by Duncan's multiple range test (DMRT) using a commercially available statistics software package (SPSS ${ }^{\circledR}$ for Windows, V. 17.0, Chicago, USA). Results were presented as means \pm SD. $P$ values $<0.05$ were regarded as statistically significant.

\section{RESULT AND DISCUSSION}

Table 1 shows the levels of enzymatic (SOD, CAT, GPx and GST) and Figure 1, Figure 2, Figure 3 and Figure 4 shows the non-enzymatic anti-oxidants (LPO, GSH, vitamin C and vitamin E) in control and the experimental groups. A significant decreased was noted in the level of both enzymatic and non-enzymatic anti-oxidants were noted in DOX induced rats and the LPO level is increased when compared with the control. After the treatment of ethanolic extract of T. catappa leaves, T. chebula fruits and isopropranolol increased the anti-oxidants level near to the normal in a dose dependent manner. The higher concentration of $300 \mathrm{mg} / \mathrm{kg}$ of the extracts has a higher activity when compared to the concentration of $200 \mathrm{mg} / \mathrm{kg}$ of the extracts of both the plants. According to the present results, T. chebula fruits have a maximum effect than that of the T. catappa leaves on enzymatic and non-enzymatic anti-oxidants. In the extracts alone treated group results similar to the control group.
Table 1: Levels of SOD, CAT, GPx and GST in cardiac tissues of control and experimental group of rats.

\begin{tabular}{ccccc}
\hline GROUPS & $\begin{array}{c}\text { SOD } \\
\text { (U/mg/ } \\
\text { protein) }\end{array}$ & $\begin{array}{c}\text { CAT } \\
\text { (nM of } \mathrm{H}_{2} \mathrm{O}_{2} \\
\text { consumed/ } \\
\text { min/mg of } \\
\text { protein) }\end{array}$ & $\begin{array}{c}\text { GPx } \\
\text { ( } \begin{array}{c}\text { conol of GSH } \\
\text { minsumg } / \\
\text { protein) }\end{array}\end{array}$ & $\begin{array}{c}\text { GST } \\
\text { (nM of CDNB } \\
\text { conjugated/ } \\
\text { min/mg of } \\
\text { protein) }\end{array}$ \\
\hline I & $4.93 \pm 0.02^{\mathrm{a}}$ & $4.06 \pm 0.78^{\mathrm{a}}$ & $3.10 \pm 0.03^{\mathrm{a}}$ & $72.54 \pm 2.13^{\mathrm{a}}$ \\
II & $0.63 \pm 0.04^{\mathrm{b}}$ & $2.14 \pm 0.07^{\mathrm{b}}$ & $0.26 \pm 0.02^{\mathrm{b}}$ & $40.37 \pm 1.08^{\mathrm{b}}$ \\
III & $4.97 \pm 0.03^{\mathrm{a}}$ & $4.12 \pm 0.91^{\mathrm{c}}$ & $3.12 \pm 0.01^{\mathrm{a}}$ & $73.88 \pm 2.12^{\mathrm{a}}$ \\
IV & $4.94 \pm 0.01^{\mathrm{a}}$ & $4.07 \pm 0.67^{\mathrm{a}}$ & $3.10 \pm 0.02^{\mathrm{a}}$ & $72.34 \pm 1.06^{\mathrm{a}}$ \\
V & $2.22 \pm 0.26^{\mathrm{c}}$ & $2.55 \pm 0.08^{\mathrm{d}}$ & $2.15 \pm 0.02^{\mathrm{c}}$ & $58.28 \pm 2.07^{\mathrm{c}}$ \\
VI & $4.12 \pm 0.05^{\mathrm{d}}$ & $3.56 \pm 0.09^{\mathrm{e}}$ & $2.96 \pm 0.02^{\mathrm{d}}$ & $64.95 \pm 1.52^{\mathrm{d}}$ \\
VII & $2.99 \pm 0.04^{\mathrm{e}}$ & $2.89 \pm 0.09^{\mathrm{f}}$ & $2.18 \pm 0.01^{\mathrm{c}}$ & $60.42 \pm 1.04^{\mathrm{e}}$ \\
VIII & $4.79 \pm 0.01^{\mathrm{f}}$ & $3.99 \pm 0.38^{\mathrm{g}}$ & $2.99 \pm 0.02^{\mathrm{d}}$ & $69.49 \pm 2.15^{\mathrm{f}}$ \\
IX & $4.91 \pm 0.02^{\mathrm{a}}$ & $4.09 \pm 0.89^{\mathrm{a}, \mathrm{c}}$ & $3.12 \pm 0.01^{\mathrm{a}, \mathrm{c}}$ & $72.32 \pm 1.21^{\mathrm{a}}$ \\
\hline
\end{tabular}

Values are expressed as mean \pm SD for six rats in each group

Values not sharing a common marking $(\mathrm{a}, \mathrm{b}, \mathrm{c} . . . .$.$) differ significantly at p \leq 0.05$ (DMRT)

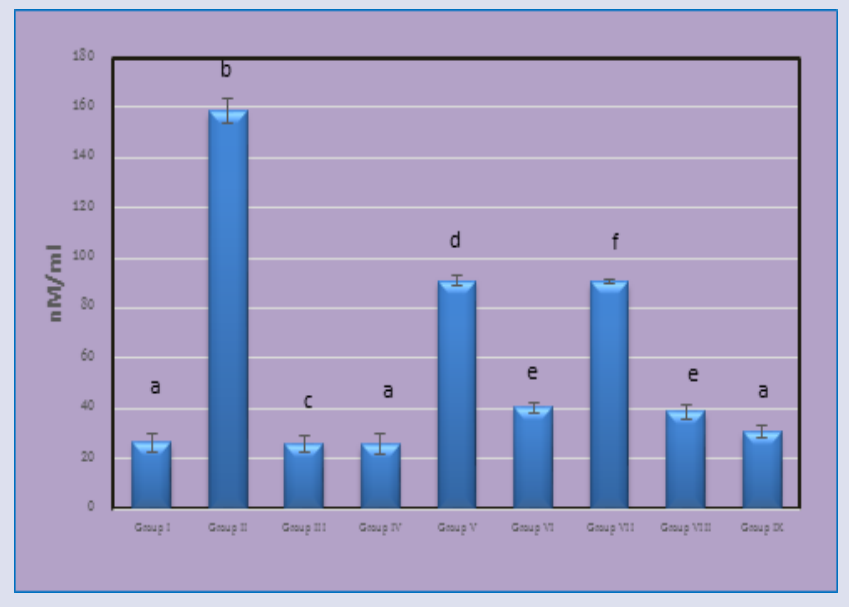

Figure 1: LPO level in plant extract treated and untreated rats.

The DOX in the cardiac muscles is converted into the semi quinone form, this is toxic and short lived, it reacts with molecular oxygen and it forms the ROS. ${ }^{18}$ DOX and its metabolites reduces the oxidant level and produces the abnormal free radical generation in the heart. ${ }^{19}$ The previous clinical studies also support the increased oxidative stress associated with DOX causes the cardiomyopathy that leads to the heart failure. ${ }^{20} \mathrm{In}$ the present study, the enzymatic anti-oxidants of SOD, CAT, GPx, GST and GSH levels are significantly $(P<0.05)$ reduced in the DOX induced animals. After the treatment of T. catappa leaves and T. chebula fruits the levels of enzymatic anti-oxidants are returned back to the normal.

SOD is an effective anti-oxidant enzyme, it potentially converts the toxic superoxide radical to $\mathrm{H}_{2} \mathrm{O}_{2}{ }^{21}$ In the DOX treated rates, the toxin which increases the lipid peroxidation and it increases the oxidative stress. This reduces the anti-oxidants levels in myocardium. The similar changes are also noted in the previous studies. ${ }^{22}$ After, the treatment of T. catappa leaves and T. chebula the levels are increased. This may due to the reduction 


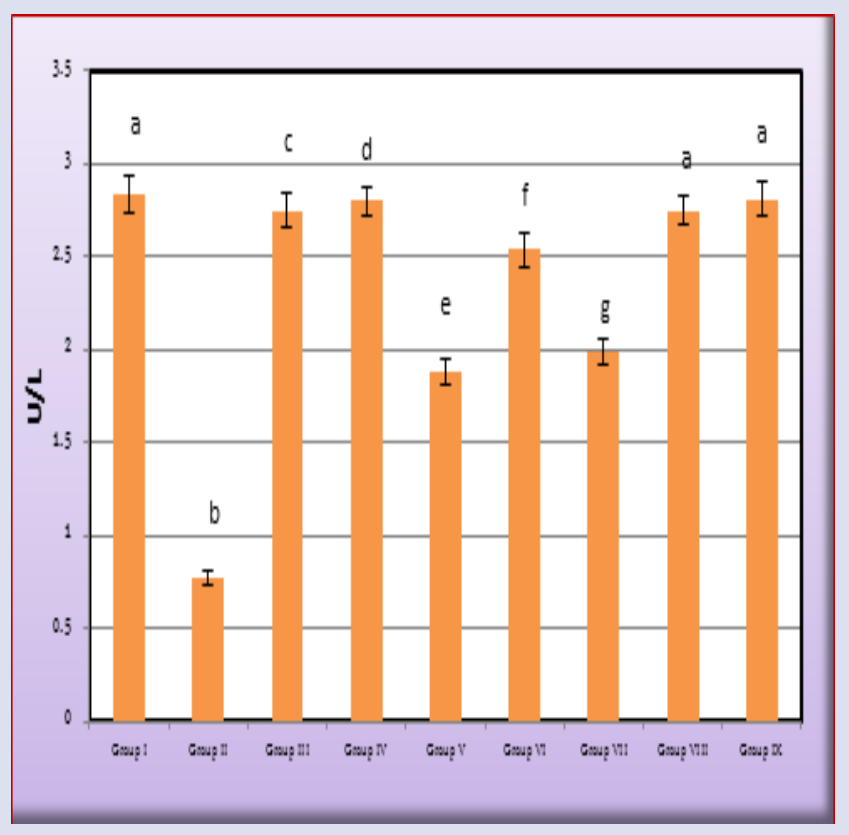

Figure 2: GSH level in plant extract treated and untreated rats Values are expressed as means \pm SD for six rats in each group Values not sharing a common marking $(a, b, c \ldots . .$.$) differ significantly$ at $p \leq 0.05$ (DMRT)

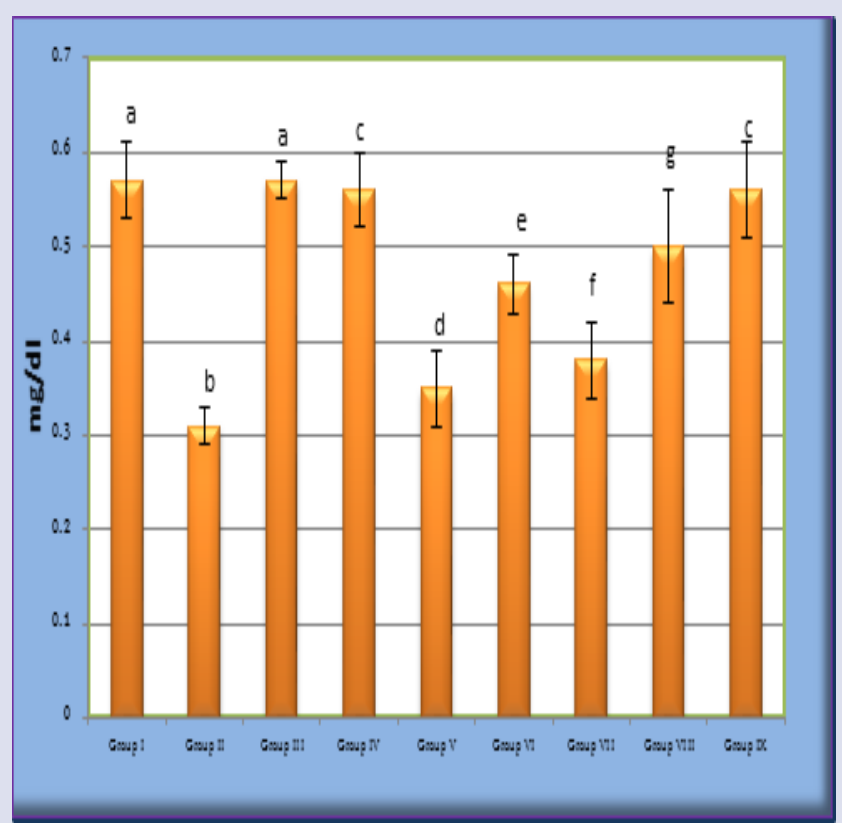

Figure 4: Vitamin E level in treated and untreated rats. Values are expressed as means \pm SD for six rats in each group Values not sharing a common marking $(a, b, c \ldots . .$.$) differ significantly$ at $p \leq 0.05$ (DMRT)

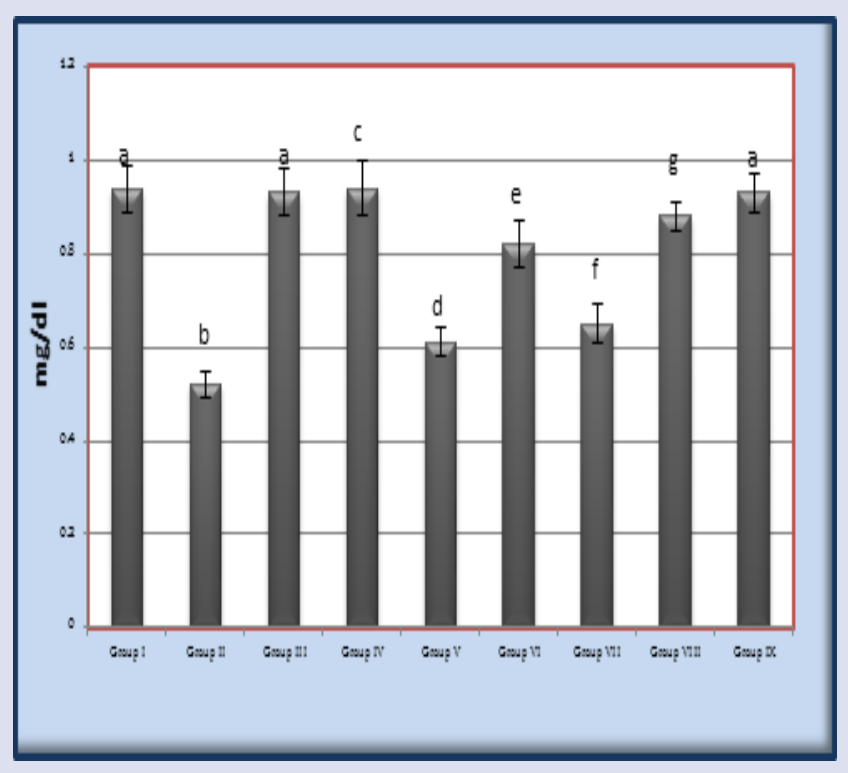

Figure 3: Vitamin C level in plant extract treated and untreated rats. of oxidative stress in the T. catappa leaves and T. chebula treated rats. These reduced oxidative stress may induces the antioxidant level. The similar effect is noted in the sesamol treated DOX induced rats. ${ }^{23}$

CAT is an antioxidant enzyme, which is present in the tissues of the heart, liver etc. It mainly involves the decomposition of $\mathrm{H}_{2} \mathrm{O}_{2}$. This $\mathrm{H}_{2} \mathrm{O}_{2}$ may damage the tissue, it was inhibited by the action of CAT enzyme. In the present study, the level of CAT is reduced in the toxin DOX induced rats. After the treatment of T. catappa leaves and T. chebula the levels are returned back to the normal. This may due to the reduction of oxidative stress by the extracts. The similar effect is noted in the Vennila and Pugalendi (2010) in the sesamol treated rats. ${ }^{24}$

GSH is an important free radical scavenger. ${ }^{25}$ Decreased level of GSH reduces the ability of cells and thereby enhances the level of LPO. In the present study, the levels of GSH is reduced in the DOX rats, it may due to the increasing concentration of LPO. After, the treatment of T. catappa leaves and T. chebula the levels are significantly $(P<0.05)$ increased and it return back to the normal.

Vitamin E is a lipid soluble and Vitamin C is a water soluble anti-oxidants, which are present in the cellular membranes. The vitamin $\mathrm{E}$ is mainly involved in the suppression of free radicals and vitamin $\mathrm{C}$ is involved in the recycling of vitamin $\mathrm{E}$ as the free radical scavenger. Vitamin $\mathrm{E}$ and vitamin $\mathrm{C}$ are maintained in the active form by GSH. The levels of vitamin $\mathrm{E}$ and vitamin $\mathrm{C}$ are decreased in the DOX treated rats. The levels are restored to the normal in T. catappa leaves and T. chebula treated rats.

\section{CONCLUSION}

The results proved that the ethanolic extracts of T. catappa leaves and T. chebula fruits may effectively regulate the enzymatic and non-enzymatic antioxidant status in the DOX induced toxicity rats. It may be the reason for its various pharmacological properties. On the basis of these findings and other scientific evidences supports T. catappa leaves and T. chebula fruits may be used to treat various disorders due to the imbalance of antioxidant levels. 


\section{ACKNOWLEDGEMENT}

The authors are greatful to Dr. Sridharan, Srimath Andavan Arts and Science College, Trichy.

\section{CONFLICT OF INTEREST}

The authors declare no conflict of interest.

\section{ABBREVIATIONS}

T. catappa: Terminalia catappa; T. chebula: Terminalia chebula; DOX : Doxorubicin: ; SOD: Superoxide dismutase; CAT: Catalase; GSH: Reduced glutathione; GST: Glutathione-S-Transferase; GPx: Glutathione peroxidase; LPO: Lipid peroxide.

\section{REFERENCES}

1. Hannah R, Vasanthi, Parameswari RP. Indian Spices for Healthy Heart - An Overview. Current Cardiology Review. 2010;6(4):274-9.

2. Taganna JC, Quanico JP, Perono RM, Amor EC, Rivera WL. Tannin-rich fraction from Terminalia catappa inhibits quorum sensing (QS) in chromo bacterium violaceum and the QS-controlled bio film maturation and Las Astaphyolytic activity in Pseudomonas aeruginosa. J Ethno Pharmacol. 2011;34(3):865-71.

3. Fan YM, Xu LZ, Gao J, Wang Y, Tang XH, Zhao XN. Phytochemical and antiinflammatory studies on Terminalia catappa. Fitoterapia. 2004;75(3-4):253-60.

4. Ahmed SM, Vrushabendra S, Gopkumar P, Dhanapal R, Chandrashekara VM. Anti-diabetic Activity of Terminalia catappa Linn. Leaf extracts in alloxan-induced diabetic rats. Iranian J Pharmacol Ther. 2005;4(1):36-9.

5. Sheik JB, Jayashankar RV, Sudha RY, Koshma M, Hanumanthu G, Dadakhalandar S A review on Terminalia chebula. International Journal of Pharmacological Research. 2017;7(10):187-91.

6. Upadhyay A, Singh DK. Molluscicidal activity of Sapindus mukorossi and Terminalia chebula against the fresh water snail Lymnaea acuminate. Chemosphere. 2011;83(4):5.

7. Lin LT, Chen TY, Chung CY, Noyce RS, GrindleyTB, McCormick C, et al. Hydrolyzable tannins (chebulagic acid and punicalagin) target viral glycoprotein-glycosaminoglycan interactions to inhibit herpes simplex virus 1 entry and cell-to-cell spread. Journal of Virol. 2011;85(9):5

8. Ponnusankar S, Pandit S, Babu R, Bandyopadhyay A, Mukheriee PK. Cytochrome P450 inhibitory potential of Triphala-A Rasayana from Ayurveda. Journal of Ethnopharmacol. 2011;133(1):5.

9. Tasduq SA, Singh K, Satti NK, Gupta DK, Suri KA. Terminalia chebula (fruits) prevents liver toxicity caused by sub-chronic administration of rifampicin, isoniazid and pyrazinamide in combination. Hum Exp Toxicol. 2006;25(3):8.

10. Gohel A, McCarthy MB, Gronowic Z. Estrogen prevents glucocorticoid induced apoptosis in oesteoblasts in vivo and in vitro. Endocrinology. 1999;140(11):5339-47.

11. Carlberg, Manervick B. Biochemical studies on hypoglyceamic effect of blood glutathione. J Biol Chem. 1975;250(14):5475-80.

12. Rotruck JT, Pope AL, Ganther HE. Selenium: Biochemical role as a component of Glutathione peroxidase, purification and assay. Science. 1973;179(4073):588-90

13. Kakkar P, Das B, Viswanathan PN. A modified spectrophotometric assay of superoxide dismutase. Indian J Biochem Biophys. 1984;21:130-2.

14. Habig HW, Jakoby WB. Assay for differentiation of glutathione Stransferases. Methods Enzymol. 1981;77:398-405.

15. Sinha AK. Colorimetric assay of catalase. Anal Biochemal. 1972;47(2):389-94

16. Roe JH, Kuether CA. The determination of ascorbic acid in whole blood and urine through the 2, 4-dinitrophenylhydrazine derivative of dehydroascorbic acid. J Biol Chem. 1943;11:145-64.

17. Baker H, Frank O, DeAngelis B, Feingold S. Plasma tocopherol in man at various times after ingesting free or acetylated tocopherol. Nutr Res. 1980;21(4):531-6.

18. Oliveira NJF, deMelo MM. Intoxicacoesrelacionadasaingestao de polpacitricaembovinos. Veterinaria Noticias. Uberlandia. 2004;10(1):111-20.

19. King J. In PracClini Enzymology. Nostrand Co, London. 1965;83-93.

20. Thanasekaran J, Cheng-Ying $H$, Jie-Jen L, Josen-Rong S. Experimental and clinical pharmacology of Andrographispaniculata and its major bioactive phytoconstituent Andrographolide. Evidence-Based Complementary and Alternative Medicine. 2003;1-16.

21. Reiter RJD, Tan X, Osuna C, Gitto E. Actions of melatonin in the reduction of oxidative stress: a review. J Biomed Sci. 2000;7(6):444-58.

22. Puri SC, Verma $V$, Amna T, Qazi GN, Spiteller M. An endophytic fungus from Nothapodytes foetida that produces camptothecin. J Nat Prod. 2005;68(12):1717-9

23. Anusha C, Mohamed STS. Antioxidant, lipid lowering and membrane stabilization effect of sesamol against doxorubicin induced cardiomyopathy in experimental rats. Bio Med Research International. 2013;1-5.

24. Vennila L, Pugalendi KV. Protective effect of sesamol against myocardial infarction caused by isoproterenol in Wistar rats. Redox Report. 2010;15(1):36-42.

25. Singh RJ. Glutathione: A marker and antioxidant for aging. Journal of Laboratory and Clinical Medicine. 2002;140(6):380-1.

\section{GRAPHICAL ABSTRACT}

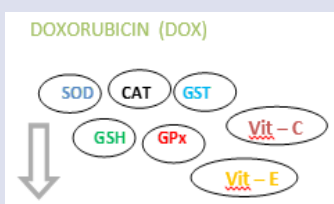

Doxorubicin treated + Ethanolic extract of $T$. catappa leaf and $T$. chebula fruit

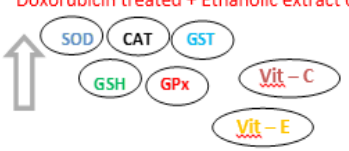

DOXORUBICIN (DOX)
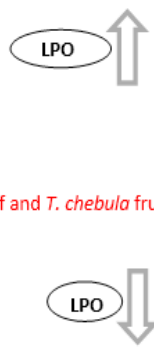

\section{SUMMARY}

- Terminalia catappa Leaves and Terminalia chebula Fruits have been traditionally used to treat various diseases. In the present findings it has been proved that the both plants have anti-oxidant properties in doxorubicin toxicity.

\section{ABOUT AUTHORS}

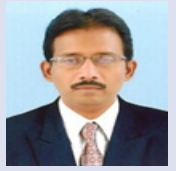

Dr. Arumugam Vijaya Anand, is an Associate Professor and Head, Department of Human Genetics and Molecular Biology. He has more than 20 years of teaching and research experiences. His area of interest is Phytopharmacology, Clinical Biochemistry and Medical Genetics.

Cite this article: Punniyakotti $\mathrm{P}$, Rengarajan RL, Velayuthaprabhu S, Vijayakumar K, Manikandan R, Anand AV. Protective Effect of Terminalia catappa Leaves and Terminalia chebula Fruits on the Enzymatic and Non-enzymatic Anti-oxidant Levels in the Doxorubicin Induced Toxicity Rats. Pharmacog J. 2019;11(2):346-9. 